\title{
PAGYVENUSIŲ ŽMONIŲ KRITIMAI: RIZIKOS VEIKSNIAI IR PREVENCIJOS GALIMYBÉS
}

\author{
Vaiva Strukčinskaitė ${ }^{1}$, Sigutė Norkienè $\dot{e}^{2,3}$, Birutė Strukčinskiené $\dot{3}^{3}$ \\ ${ }^{1}$ Vilniaus universiteto Medicinos fakultetas, ${ }^{2}$ Klaipedos jürininku ligonine, \\ ${ }^{3}$ Klaipédos universiteto Sveikatos mokslu fakultetas
}

\author{
Raktažodžiai: pagyvenę žmonès, kritimai, rizikos \\ veiksniai, prevencija.
}

\begin{abstract}
Santrauka
Visuomenès senejjimas yra viena iš svarbiausių XXI amžiaus problemų. Pagyvenusiems žmonėms ypač pavojingi sužalojimai, nes didina pagyvenusių žmonių mirtingumą, neigalumą ir blogina gyvenimo kokybę vyresniame amžiuje.

Darbo tikslas buvo analizuoti pagyvenusių žmonių kritimų rizikos veiksnius ir prevencijos galimybes. Atlikta mokslinès literatūros apžvalga. Naudota dokumentų ir dokumentinių šaltinių analizè.

Tyrimo metu atskleista, kad kritimai yra pagrindiné pagyvenusių žmonių mirties priežastis. Kritimų rizikos veiksniai yra vidiniai (susiję su anatominiais - fiziologiniais pokyčiais senatvejje) ir išoriniai (susiję su nesaugia aplinka). Kritimų pavojų didina pablogèjusi pagyvenusių žmonių eisena, laikysena, susilpnèję raumenys. Regos ir klausos problemos bei kitos lètinès ligos taip pat gali būti kritimų rizikos veiksniais. Nesaugi aplinka namuose bei keliuose, pagalbinių ịtaisų bei priemonių stoka yra išoriniai kritimų rizikos veiksniai.

Pagrindinès pagyvenusių žmonių sužalojimų prevencijos priemonės yra pusiausvyros lavinimas, fizinio aktyvumo skatinimas ir saugios aplinkos kūrimas. Švietimas, informavimas, regos ir klausos problemų sprendimas, tinkamas medikamentų vartojimas, pagalbinių itaisų ir priemonių naudojimas yra rekomenduotinos priemonès, padedančios stiprinti pagyvenusių žmonių saugą ir mažinti kritimų riziką.
\end{abstract}

\section{Ivadas}

Senų žmonių sveikatos išsaugojimas ir funkcinio savarankiškumo išlaikymas keliamas kaip vienas pagrindinių uždavinių visam Europos regionui. Svarbu užtikrinti pagy- venusių žmonių geresnę sveikatą ir gyvenimo kokybę [1]. Fiziologiniai senėjimo pokyčiai, tokie kaip raumenų jègos sumažèjimas, suvokimo, sąnarių judesių amplitudès sutrikimai, reakcijos laiko sulètėjimas bei pokyčiai sensorinejje sistemoje daro įtaką pusiausvyrai ir jos kontrolès sutrikimams [2]. Gera pusiausvyra ir mobilumas yra pagrindinès sėkmingo kasdienio gyvenimo bei mėgstamos veiklos prielaidos. Tačiau kritimai yra dažni tarp vyresnio amžiaus žmonių, ir jie lemia rimtus sužalojimus, savarankiškumo praradimą bei slaugą namuose. Kasmet pasaulyje registruojama apie 37,3 milijonai sunkių sužalojimų dèl kritimų, kai reikia gydytojo pagalbos [3]. Mirtingumas nuo nukritimų Lietuvoje 100000 gyventojų padidejo nuo 9,8 (2010 metais) iki 12,0 (2014 metais), pralenkdamas eilę metų pirmavusią išorinių mirties priežasčių kategoriją - eismo įvykius [4]. Kritimų rizikos veiksnių supratimas, identifikavimas ir prevencinių priemonių taikymas yra svarbūs norint išvengti kritimų ir su jais susijusių traumų.

Darbo tikslas - analizuoti pagyvenusių žmonių kritimų rizikos veiksnius ir prevencijos galimybes.

\section{Medžiaga ir metodai}

Atlikta mokslinès literatūros apžvalga. Naudota dokumentų ir dokumentinių šaltinių analizè, aprašomoji analizè. Darbe naudoti dokumentai ir dokumentiniai šaltiniai yra pirminiai, reguliatyviniai/direktyviniai, komunikatyviniai, informaciniai.

\section{Rezultatai ir jų aptarimas}

Senėjimas ir senatviniai organizmo pokyčiai. Visuomenès senèjimas yra viena iš svarbiausių XXI amžiaus problemų. Prognozuojama, kad iki 2050 metų gimstamumas Europoje didès nežymiai, vidutinè tikètina gyvenimo trukmé ilgès, tad senyvo amžiaus žmonių neišvengiamai daugès [1]. Senéjimas tampa vis aktualesne problema, nes pagyvenusių ir senyvo amžiaus žmonių populiacija vis dideja, tuo pačiu didejja ịvairių ligų ir negalių dažnis [2]. Se- 
nejjimas - tai sudètingas procesas, kurio eigoje kinta visų žmogaus organų ir sistemų struktūra, funkcijos ypatumai ir adaptacinès galimybès [5]. Amžių, nuo kurio prasideda senatvè, demografijos specialistai vertina skirtingai. Jungtinès Tautos pagyvenusio amžiaus žmones įvardija kaip 65 metų amžiaus ir vyresnius [6]. Žmogui senstant atsiranda ịvairūs fiziologiniai pokyčiai.

Nervų sistemos pokyčiai. Nervų sistemos pokyčiai paveikia visas fiziologines žmogaus organizmo sistemas. Neuronai įvairiose organizmo vietose pamažu žūsta, dalis praranda aksonus ir dendritus. Pagyvenusio amžiaus žmonių refleksai būna sulètėję, sumažěja kraujo tiekimas smegenims, pablogèja trumpalaikè atmintis, gali prasidèti kai kurios su amžiumi susijusios nervų ligos, tokios kaip Alzheimerio ir Parkinsono ligos. Parkinsono ligos eigoje pakinta laikysena ir eisena $[7,8]$.

Jutimo organų pokyčiai. Senstant trinka jutimo organų veikla, silpsta rega ir klausa, nes sumažeja nervinių skaidulų skaičius regos ir klausos nervuose. Senstant sumažèja regos aštrumas, storejja ragena ir akys netenka blizgesio. Regèjimą silpnina ịvairios akių ligos - senatvinè katarakta bei glaukoma. Nusilpsta spalvų skyrimas ir pablogėja prieblandinè rega, nes žūsta dalis kolbelių ir lazdelių, kurios apsprendžia šị gebèjimą [8]. Vizualinès sistemos perduodama informacija centrinei nervų sistemai yra nepakankama, dẻl to gali trikti žmogaus kūno padèties suvokimas erdvèje. Regèjimas yra efektyvios pusiausvyros pagrindinis jutiklis, tad pusiausvyra žymiai pablogèja silpnèjant regèjimui [9]. Vykstant senejjimo procesams keičiasi atstumo suvokimas ir reakcijos greitis.

Judejimo ir atramos sistema. Senatveje kinta laikysena, eisena, judesiai. Reteja kaulinis audinys, kaulai tampa trapūs, lengviau lūžta [8]. Dažniausiai pasitaikantys lūžiai šlaunies, riešo ir žasto kaulų srityse. Pavyzdžiui, dẻl kaulų retejjimo šlaunikauli galima sulaužyti $2-2,5$ karto mažesne jèga, negu jaunystejje. Nustatyta, kad vyresnio amžiaus asmenims dažnai įvyksta šlaunikaulio kaklo lūžiai [10]. Viena iš lètinių ligų, galinčių bloginti pagyvenusių žmonių sveikatą, yra osteoporozè. Tai sisteminè kaulų liga, kuriai būdinga maža kaulinè masè dèl kaulų tankio sumažèjimo, dèl to padidèja kaulų trapumas bei išauga lūžių rizika [11]. Lietuvoje ja serga apie 250000 žmonių [1]. Senatvejje progresuoja osteochondrozè, vystosi tarpslankstelinių diskų distrofiniai ir destrukciniai pakitimai, stuburo raiščiai kietèja ir trumpejja, stuburas deformuojasi $[8,10]$. Šie pakitimai gali sukelti laikysenos, pusiausvyros ir eisenos pakitimus, funkcijos sutrikimus ir skausmą.

Kvėpavimo sistemos pokyčiai. Senstant alveolès po truputi pradeda nykti, todèl pablogèja dujų apykaita plaučiuose. Su amžiumi silpsta kvėpuojamieji krūtinès ląstos raumenys, sumažèja plaučių elastingumas, todèl sumažèja i plaučius įkvepiamo oro tūris ir arterinio kraujo prisotinimas deguonimi $[8,12]$. Dèl šių priežasčiu pagyvenusio amžiaus žmonèms atsiranda galvos svaigimas.

Širdies ir kraujagysliu sistemos pakitimai. Senstant arterijų sienele storeja ir standeja, ji praranda tamprumą ir elastingumą. Nusilpsta širdis (nes dalị raumeninių ląstelių pakeičia skaidulinis audinys), mažèja širdies susitraukimų jèga, širdies darbas yra prasčiau suderinamas su apkrova, suletėja širdies bei kraujagyslių sistemos funkcijos atsistatymas po fizinio krūvio, mažèja fizinis pajègumas [8-10]. Senstant didejja sistolinis arterinis kraujospūdis, mažèja veninis kraujospūdis, mažèja minutinis širdies tūris.

Pusiausvyros pokyčiai senstant. Senstant pablogèja pusiausvyra. Senejjimo procesai sukelia gebejjimo išlaikyti kūno padèti erdvejje pablogèjimą, sensorinių sistemų funkcijos pablogejjimą, raumenu jègos, apimties ir masès mažèjimą, raumenų skaidulų skaičiaus ir motorinių vienetų pokyčius, laikysenos pakitimus ir pusiausvyros kontrolès mažèjimą [13]. Bet kurio pusiausvyros komponento veiklos nusilpimas žmogaus organizmui senstant mažina stabilumą ir trikdo eiseną [14]. Pusiausvyra blogejja arba yra visiškai prarandama, kai sutrinka nors viena pusiausvyros grandis. Pusiausvyros kontrolè reikalauja gero regejjimo, somatosensorinių vestibulinių funkcijų dalyvavimo ir jų prisitaikymo prie kintančių sąlygų [15]. Pagyvenusiems žmonèms būdingas somatosensorinès, vestibulinès ir regos sistemų pokyčiai bei žymus šių funkcijų pablogejjimas [16]. Kai informacija iš regimosios, vestibulinès ir propriorecepsinės sistemų nèra tinkamai pajungiama i centrinę nervų sistemą galimas pusiausvyros sutrikimas, o tai gali sukelti kritimą. Atlikti tyrimai parodè, kad senų žmonių pusiausvyros kontrolè, lyginant su jaunais žmonèmis, yra sumažèjusi. Dažniausiai vyresnio amžiaus žmonių pusiausvyros sutrikimai yra susiję su sumažèjusiu funkciniu pajėgumu ir padidejusia galimybe nukristi [17].

Vaistų poveikis pagyvenusiems žmonėms. Pagyvenusių žmonių vaistų vartojimas gali sąlygoti pusiausvyros pakitimus. Pasak Bagdono ir kt. (2009), keturi iš penkių pagyvenusių žmonių serga lètine liga. 40 proc. vyresnio amžiaus žmonių vartoja penkis ar daugiau, o 12 proc. vartoja 10 ar daugiau skirtingų vaistų per savaitę. Šalutinis vaistų poveikis yra du kartus dažnesnis 65 metų amžiaus ir vyresniems žmonėms, negu jaunesniems asmenims Dèl vaistų vartojimo išsivysto vertikalios laikysenos kontrolès sutrikimas, todèl gali pasireikšti pusiausvyros nestabilumas, siūbavimas ir silpnumas [9].

Pagyvenusio amžiaus žmonių kritimai. Vyresnio amžiaus žmonès yra veikiami senatvinių organizmo pokyčių, blogèja jų koordinacija, trinka pusiausvyra, todèl didèja 
kritimų rizika. Kritimas - ivykis, kai žmogus netyčia nukrenta ant žemès, grindų ar kito žemesnio paviršiaus [18]. Kritimai yra viena iš aktualiausių pagyvenusių žmonių problemų, nes jų pasekmès ženkliai sutrikdo žmonių sveikatą ir didina jų socialinę izoliaciją. Dažniausiai vyresnio amžiaus žmonès susižaloja krisdami. Pagyvenusio amžiaus žmonių grupėse kritimai gali sukelti sunkias traumas ir mirti. Sterling ir kt. (2001) nustatè, kad dèl kritimų sužalojimų sunkumas ir mirčių atvejai buvo dvigubai didesni tarp vyresnio amžiaus žmonių nei tarp jaunų asmenų. Kiekvienais metais nukrenta kas trečias pagyvenęs žmogus, tačiau mažiau negu pusè nukritusių asmenų praneša apie tai savo sveikatos priežiūros specialistui $[19,20]$. Jungtinèse Amerikos Valstijose 2013 metais 2,5 mln. pagyvenusių žmonių nukrito ir buvo išvežti greitaja medicinos pagalba, daugiau nei 734 tūkst. iš jų buvo paguldyti ị ligoninę [21].

Pasaulio sveikatos organizacijos duomenimis, kasmet nuo kritimų miršta apie 424000 žmonių. Didžiausią mirtingumą nuo kritimų sudaro žemo ir vidutinio ekonominio lygio šalių vyrai ir vyresni nei $70 \mathrm{~m}$. amžiaus suaugusieji. Europos regione 2002 metais nuo kritimų miré beveik 80 000 žmonių, o 40 proc. mirusių nuo kritimų sudare 80 metų ir vyresnio amžiaus žmonès [22]. Kasmet pasaulyje registruojama apie 37,3 milijonai sunkių sužalojimų dèl kritimų, kai reikia gydytojo pagalbos [3]. Tiesioginès ir netiesioginès šių traumų gydymo išlaidos gerokai didesnès nei kitų traumų. Vien Jungtinèse Amerikos Valstijose 2013 metais tiesioginès medicininès išlaidos, atsiradusios dèl kritimų, sudare 34 milijardus JAV dolerių [21].

Mirtingumas nuo nukritimų Lietuvoje 100000 gyventojų padidèjo nuo 9,8 (2010 metais) iki 12,0 (2014 metais), pralenkdamas eilę metų pirmavusią išorinių mirties priežasčių kategoriją - eismo įvykius [5]. V. Alekna ir bendraautoriai (2002), ištyrę 250 vyresnių nei 60 metų amžiaus asmenų, nustatè, kad bent vieną kartą per metus krito 34,4 proc. tiriamujų, o M. Tamulaitienè ir kt. (2009) savo atlikto tyrimo išvadose teige, kad vieną kartą per metus griuvo 35,3 proc. tirtų 65 metų ir vyresnio amžiaus moterų [23, 24]. A. Juozulyno ir kt. (2012) atlikto tyrimo metu paaiškejjo, kad vieną kartą per metus griuvo 30,8 proc. tirtų 60 metų ir vyresnio amžiaus moterų [1].

Nukritus galimi ịvairūs sužalojimai: gali lūžti ar išnirti kaulai, galimi sumušimai, raiščiu patempimai, žaizdos, galvos ar stuburo smegenų pažeidimai. 2012 metais atlikto tyrimo metu buvo nustatyta, kad kas ketvirta nukritusi moteris patyrẻ kaulų lūžius [1]. Po kritimų gali atsirasti trumpalaikis ar ilgalaikis neiggalumas, ypač patyrus galvos traumą, dèl kurios asmeniui sutrinka judejimas, mąstymas ir jutimai. Mažějant pagyvenusių žmonių kaulų stiprumui, padidèjęs polinkis kristi senatvèje didina kaulų lūžių ri- ziką. Kanadoje 2008 metais daugiau negu $60 \%$ procentų stacionare dèl sužalojimų gydytų pagyvenusio amžiaus žmonių gydèsi dẻl kritimų, kurių metu įvyko šlaunikaulio, viršutinių galūnių lūžiai ar smegenų traumos [25]. Pačios grèsmingiausios sveikatai kritimų pasekmès yra šlaunikaulio viršutinès dalies lūžiai. Didžioji dalis pagyvenusių asmenų po šlaunikaulio lūžių patiria komplikacijų. Po tokių lūžių, 50 proc. senų žmonių judèjimas būna sutrikęs, dalis jų nebegali savarankiškai judèti ir net 20 proc. pagyvenusių žmonių miršta per pirmuosius metus po traumos [21].

Pagyvenusių žmonių kritimų rizikos veiksniai. Pagyvenusio amžiaus asmenų kritimai skiriasi nuo kritimų kitose amžiaus grupèse. Dauguma pagyvenusių žmonių kritimų yra susiję su jų anatominiais-fiziologiniais ypatumais bei jų sveikatos problemomis. Kritimų priežasčių gali būti daug ir ịvairių, gali būti keletas kritimo priežasčiu vienu metu, o kartotinių kritimų priežastys gali būti vis kitos. Vyresnio amžiaus žmonèms būdinga kelių rizikos veiksnių itaka.

Kritimų rizikos veiksniai yra skirstomi ị du tipus: vidinius, susijusius su pačiu žmogumi, ir išorinius, t.y. aplin-

1 lentelè. Pagyvenusių žmonių sužalojimų nuo kritimų veiksniai (parengta autoriu, remiantis PSO, 2012 [18]).

\begin{tabular}{|c|c|c|}
\hline Tipas & Pavyzdžiai & Ryšys su trauma \\
\hline $\begin{array}{l}\text { Vidi- } \\
\text { nis }\end{array}$ & $\begin{array}{l}\text { Sumažèjęs kaulų ir kūno stipru- } \\
\text { mas } \\
\text { Susirgimai/ligos, kurios daro } \\
\text { įtaką pusiausvyrai ir mobilumui } \\
\text { Sutrumpėjęs reakcijos laikas, } \\
\text { sumažèjęs budrumas } \\
\text { Blogesnè pusiausvyra ir netvir- } \\
\text { ta eisena } \\
\text { Regèjimo sutrikimai } \\
\text { Pažintinių funkcijų sutrikimai }\end{array}$ & $\begin{array}{l}\text { Dèl silpnesnių } \\
\text { kaulų ir kitų ligų, } \\
\text { kritimų metu gali } \\
\text { ivykti trauma } \\
\text { Netikètas galvos } \\
\text { svaigimas dėl pu- } \\
\text { siausvyros sutri- } \\
\text { kimo ar ligos } \\
\text { Susilpnèjęs gebė- } \\
\text { jimas identifikuo- } \\
\text { ti kritimo pavojus } \\
\text { Sumažejjęs gebejji- } \\
\text { mas pašalinti arba } \\
\text { koreguoti užkliu- } \\
\text { vimo ir kritimo } \\
\text { pavojus }\end{array}$ \\
\hline $\begin{array}{l}\text { Išori- } \\
\text { nis }\end{array}$ & $\begin{array}{l}\text { Medikamentai } \\
\text { Nepritvirtinti kilimai } \\
\text { Nėra turėklų ir pagalbinių stry- } \\
\text { pų (vonios kambaryje, tualete, } \\
\text { kitur) } \\
\text { Netinkama avalynė, netinkama } \\
\text { apranga } \\
\text { Netinkamas apšvietimas } \\
\text { Nelygūs paviršiai, prastai pri- } \\
\text { žiūrimi šaligatviai ir keliai } \\
\text { Slidi grindų, takų, kelio danga }\end{array}$ & $\begin{array}{l}\text { Skirtingų vaistų } \\
\text { ar kitų psichoak- } \\
\text { tyvių medžiagų } \\
\text { vartojimas padidi- } \\
\text { na riziką } \\
\text { Padidëjusi tiki- } \\
\text { mybė prarasti pu- } \\
\text { siausvyrą, užkliūti } \\
\text { ar nukristi dėl ne- } \\
\text { saugios aplinkos }\end{array}$ \\
\hline
\end{tabular}


kos rizikos veiksnius [18]. Išoriniai ir vidiniai veiksniai yra tarpusavyje susiję ir veikdami vienas kitą didina kritimų riziką. Pagyvenusiems žmonėms būdingi vidiniai rizikos veiksniai susiję su anatominèmis-fiziologinèmis organizmo savybėmis ir senatviniais pokyčiais. Pagrindiniai vidiniai kritimu rizikos veiksniai - sutrikusi pusiausvyra, nestabili eisena, suprastejusi klausa ir rega bei ịvairios ligos, veikiančios šiuos aspektus. Kalbant apie kritimų ypatumus, didelès reikšmès kritimo metu turi žmogaus anatominès savybės, t.y. kūno kompozicija ir aplinkos savybės. Kaulo struktūra ir riebalų išsidèstymas turi reikšmès sužalojimų sunkumui.

Traumos sunkumui labai svarbi aplinka. Kritimo aukštis ir kritimo paviršius yra svarbūs veiksniai sužeidimų sunkumui - kuo didesnis kritimo aukštis ir kuo kietesnis paviršius, ant kurio nukrentama, tuo sunkesnè trauma [18].

1 lentelèje pateikiami sužalojimų nuo kritimų veiksniai pagyvenusiems žmonėms. Čia prie išorinių kritimų rizikos veiksniu yra priskiriami medikamentai, kuriais gydomos ịvairios ligos. Kelių, pvz., keturių skirtingų vaistų vartojimas gali sutrikdyti žmogaus orientaciją ir koordinaciją ir taip padidinti kritimų riziką. Išoriniai rizikos veiksniai apima netinkamą aprangą, nesaugią aplinką. Netinkama avalynė gali padidinti kritimų riziką. Taigi rekomenduojama patogi, tinkamo dydžio avalynė žemu kulnu, neslidžiu padu, ortopediška ir su tinkamu vidiniu padu, atitinkančiu fiziologinị pèdos linkị. Drabužiai turètų būti ne per dideli, ne su ilgais kraštais ir ne palaidi, kad individas neužkliūtų ir neužsikabintų už aplinkinių paviršių. Netinkamai parinktos pagalbinès priemonès taip pat didina kritimų riziką, todèl svarbu, kad pagalbinè priemonè būtų geros būklès, atitinkamo dydžio, ir kad ji būtų teisingai naudojama.

Fizinè aplinka, kurioje gyvena pagyvenusio amžiaus žmonès, glaudžiai susijusi su kritimais. Dauguma pagyvenusių žmonių nukritimų įvyksta patalpose, namuose [23, 26]. Pagrindiniai kritimų rizikos veiksniai namuose - siauri laiptai, laiptai, turintys keturis ir daugiau laiptelių, laiptai, prie kurių nèra pritvirtinti turèklai, slidūs paviršiai ir netinkamas apšvietimas [27]. Piščalkienès ir kt. autorių (2012) atlikto tyrimo metu buvo ištirti 500 asmenu, turinčiu 60 ir daugiau metų. Tyrimas parodè, kad dažniausiai pasitaikantys vyresnio amžiaus žmonių kritimų rizikos veiksniai namų aplinkoje - laikiklių stoka, slidžios grindys, kilimėliai bei slidus vonios dugnas. Viešose aplinkose didžiausią riziką kelia netvarkingi šaligatviai ir laiptai, slidūs keliai ir šaligatviai [2]. Pasaulio sveikatos organizacija rizikos veiksnius, turinčius įtakos pagyvenusių žmonių kritimams ir dèl jų patiriamiems sveikatos sužalojimams, suskirste i keturias grupes: biologinius, elgsenos, aplinkos ir socialinius-ekonominius [3]. Biologiniai rizikos veiksniai yra: amžius, lytis, rasè, lètinès ligos, pažintiniai sutrikimai Iš elgsenos rizikos veiksnių paminètini vaistų, alkoholio vartojimas, nepakankamas fizinis aktyvumas, netinkamos avalynès naudojimas. Nesaugiai suprojektuotas pastatas, slidžios grindys, laiptai, kilimai, nepakankamas apšvietimas, sutrūkinèję, nelygūs šaligatviai yra vieni iš daugelio aplinkos rizikos veiksnių. Tarp socialinių-ekonominių veiksnių yra žemas pajamų, išsilavinimo lygis, netinkamos gyvenimo sąlygos, bendravimo stoka ir kiti [3, 28]. Nors kritimu priežastys kinta ir yra kompleksinès, tačiau labiausiai kritimus lemiantis veiksnys yra eisenos kontrolès (pusiausvyros) sutrikimai. Šiuos sutrikimus gali lemti: paslydimas, suklupimas, susidūrimas ar fizinè sąveika su judančiais ar nejudančiais daiktais aplinkoje [3]. Tyrimai rodo, kad pagyvenę žmonès mažai mankštinasi, ne visi pakankamai skiria dèmesio fizinio aktyvumo veikloms [26]. Be to, atliekant mokslinius tyrimus paaiškejjo, kad pagyvenę žmonès neturi pakankami informacijos apie nukritimu prevencijos galimybes bei prevencines priemones, padedančias išvengti sužalojimų $[23,26]$.

Pagyvenusių žmonių kritimų prevencija. Pagyvenusių žmonių (65 metų amžiaus ir vyresnių) kritimų ir traumų nuo jų prevencijai turi būti skiriamas prioritetinis dèmesys nacionaliniu ir vietiniu sveikatos politikos lygmenimis. Nukritimų prevencijai tinka taikyti pagrindinius sužalojimų prevencijos būdus: švietimą/mokymą/informavimą, saugios aplinkos kūrimą bei teisines priemones. Nukritimų prevencijai svarbus saugios namų aplinkos kūrimas, kritimų riziką didinančių veiksnių šalinimas, saugos įrenginių, laikiklių taikymas namuose, konsultavimasis su sveikatos ir medicinos darbuotojais [26]. Aukšto ekonominio lygio šalyse jau eilę metų pagyvenusių žmonių sužalojimų prevencija, o ypač nukritimų ir traumų namuose profilaktika ir saugos stiprinimas, yra svarbi visuomenès sveikatos stiprinimo sritis. Jungtinių Amerikos Valstijų Visuomenès sveikatos priežiūros tarnyba, remdamasi įvykusių kritimų priežasčių ir aplinkybių analize, nustatè, kad dviejų trečdaliu visu mirčiu dèl nukritimu potencialiai galima būtų išvengti, nustačius ir pašalinus pavojingus aplinkos veiksnius namuose bei institucijose [29]. Veiksmingos profilaktikos programos apima išsamų individualų paciento būklès ịvertinimą, specifines rekomendacijas, susijusias tiek su aplinka, tiek ir su pačiu pacientu, pagalbiniu priemonių naudojimą, psichotropinių vaistų vartojimo ypatumus, jègos, pusiausvyros, persikèlimo pratimus, paciento priežiūrą, klubo sąnario apsaugos įtaisų naudojimą, plataus profilio mokomąsias programas bei konferencijas. JAV esantis Ligų kontrolès ir prevencijos centras (angl. Center for Disease Control and Prevention - CDC) išskiria keturių veiksmų kritimų prevencijai skirtas rekomendacijas [21]. 
- Reguliarus fizinis aktyvumas

- Medikamentų peržiūra

- Reguliarios regos patikros

- Namų aplinkos ịvertinimas

Siekiant sumažinti vyresnio ir seno amžiaus asmenu kritimų skaičių reikètų kreipti dèmesị ị žmogaus fizinio pajėgumo savybių bei pusiausvyros išsaugojimą, taip pat ì gyventojų aplinkos ir joje galimų kritimus sąlygojančiu veiksnių ịvertinimą. Kritimų prevencijoje kaip fizinis aktyvumas rekomenduojami: jègos ir pusiausvyros mankštos, hidroterapija, kineziterapija vandenyje, Tai Chi, kasdieniai pasivaikščiojimai (po 30 min.), šokiai ir individualios trenerių ar kineziterapeutų sudarytos fizinių pratimų programos [30]. Tai Chi treniruotès gerina pusiausvyrą, eiseną, lankstumą, mažina stresą bei įtampą [31, 32]. Silsupadol su bendraautoriais aprašè ịvairius pusiausvyros lavinimo metodus (Vienos užduoties metodą, Dviejų užduočių su fiksuoto tikslo instrukcijomis metodą, Dviejų užduočių su kintančio tikslo instrukcijomis metodą) [33]. Cawthorne ir Cooksey pratimu programa gerina pusiausvyros reakcijas bei mažina tikimybę pargriūti. Ši pratimų programa nesudètinga, skirta kaklo ir pečių raumenų atpalaidavimui, akių judesių, nepriklausomai nuo galvos judesių, lavinimui, pusiausvyros treniravimui esant kintančioms aplinkos sąlygoms [34].

Fizinio aktyvumo nauda neabejotina traumų prevencijai. Pasak Z. Javtoko ir E. Mačiūno (2008), fizinis aktyvumas didina ištvermę, jègą, pusiausvyrą ir judrumą, o tai padeda gyventi savarankiškai. Be to, fizinè veikla didina kaulų tankį ir gali padèti užkirsti kelią osteoporozei[35]. Ivairios šalys, tokios kaip Naujoji Zelandija, Australija, Jungtinė Karalyste ir JAV, parenge ir igyvendino mankštu programas pagyvenusiems žmonèms, kurios buvo orientuotos i jègą, pusiausvyrą, lankstumą ir ištvermę. Šiu programų ịvertinimas parodè, kad taikant du ir daugiau šių komponentų, sumažèjo kritimų dažnis. Pratimai buvo efektyvūs vykdant juos grupèje su treneriu, arba juos atliekant individualiai [36]. Pagyvenusių žmonių kritimų prevencija apima ne tik kritimų rizikos veiksnių šalinimą, bet ir fizinio aktyvumo skatinimą. Pagyvenusio amžiaus žmonès turi būti skatinami būti fiziškai aktyvūs, siekiant išvengti kritimų ir traumų. Stiprinant pagyvenusių žmonių pusiausvyrą bei gerinant eiseną galima sumažinti traumų nuo kritimų riziką. Daugybė mokslinių tyrimų buvo atlikta norint moksliškai įrodyti fizinių pratimų naudą vyresnio amžiaus žmonèms. Tyrimai parodè, kad pratimai pagyvenusiems žmonèms gali sumažinti netvirtumą, padidinti èjimo greitị, padidinti galimybę gyventi nepriklausomai ir padidinti tikèjimą gyvenimu. Pratimai ženkliai sumažina širdies ir kraujagyslių ligų riziką ir osteoporozę. Reguliarūs pratimai pagerina pusiausvyrą ir sumažina kritimų riziką [37]. Fiziškai aktyvesnių vyresnio amžiaus žmonių pusiausvyra yra geresnè nei fiziškai neaktyvių [38]. Pagyvenusio amžiaus žmonių reabilitacijoje pagrindinis kineziterapijos tikslas pagerinti judejimo funkciją. Kineziterapeutai stengiasi padidinti pacientų raumenų jègą, pagerinti savęs suvokimą, koordinaciją, sąnarių stabilumą, judrumą ir pagerinti plaučių bei širdies darbo funkcijas. Kineziterapeutų ir fizioterapeutų vaidmuo dirbant su pagyvenusio amžiaus žmonėmis yra:

- mokyti ir padėti vaikščioti, persèsti, lipti laiptais, naudotis pagalbinemis priemonèmis;

- ịvertinti pagalbinių įtaisų ir prietaisų poreikị ir padèti juos ịsigyti;

- mankštinti didinant judesių amplitudę, jègą ir ištvermę;

- aprūpinti pakèlimo ir manipuliavimo prietaisais;

- ịvertinti ikioperacinę ir pooperacinę funkcinę būklę;

- fizinèmis priemonèmis gydyti skausmą;

- apmokyti specialių pratimų [9].

Prieš atliekant bet kokią reabilitaciją būtinas detalus paciento ištyrimas, funkcijų ịvertinimas, reabilitacinių tikslų ir uždavinių išsikèlimas. Pagyvenusio amžiaus žmonių gerontologinis tyrimas turi būti kompleksinis: atliekamas fizinis ir funkcijų vertinimas, socialinès padèties ịvertinimas bei psichologinès būklès ịvertinimas [9]. Kadangi tarp pagyvenusių amžiaus žmonių rizika nukristi yra ypač padidèjusi, todèl testuojama pusiausvyra ir eisena. Prieš užsiimant fizine veikla ir norint įvertinti kritimų riziką, daugelyje kritimų prevencijos programų yra skatinami kineziterapeuto ar gydytojo atliekami paciento ivvertinimai, regos patikros, fizinio pajëgumo ištyrimas, pusiausvyros ir eisenos vertinimai, praeityje buvusių kritimų apžvalga. Labai svarbu peržvelgti individo vartojamus medikamentus, išanalizuoti jų poveikị individui, medikamentų sąveikas su kitais vartojamais medikamentais.

Efektyviausia kritimu profilaktikos strategija - rizikos veiksniu įvertinimas ir kompleksiniu prevencinių priemonių taikymas. Pasak M. Grivnos ir kt. (2014), aplinkos pakeitimas naudojant pagrịstus architektūrinius sprendimus gali sumažinti kritimų riziką tarp padidintos kritimų rizikos grupių, tokių kaip pagyvenę žmonès ir vaikai. Paprasčiausi pavyzdžiai kuriant saugią namų aplinką, taikant kritimų prevenciją yra tokie - turéklų ir ịvairių ramsčių, laikiklių montavimas, kilimų ir atšokusių nuo grindų paviršių peržiūra ir fiksavimas, slidžių paviršių naikinimas, naudojamų kèdžių eksploatavimas saugiame aukštyje [39].

Specialus dèmesys turètų būti skiriamas pagyvenusių žmonių informavimui, švietimui ir saugaus elgesio mokymui [3]. Norint vykdyti efektyvią kritimų prevenciją svar- 
bu atkreipti dèmesi i galimas kliūtis, tokias kaip: nepakankamos žinios, nepalaikomos galimų prevencinių priemonių nuostatos, kliūtys, saugios aplinkos kūrimui, nepakankama socialinè parama, resursų bendruomeneje stoka [26]. Priemonès šioms kliūtims panaikinti galètų būti tokios: nemokamos informacijos ir tinkamų nuostatų pateikimas, pagalba montuojant saugius gaminius, kuriant saugią aplinką. Visa tai yra neịmanoma be bendruomenès narių ịsitraukimo ị veiklą, politikų ir vadovybès švietimo, finansinès paramos ir prevencinių veiksmų palaikymo.

\section{Išvados}

1. Kritimai yra pagrindinè pagyvenusių žmonių mirties priežastis.

2. Kritimų rizikos veiksniai yra vidiniai (susiję su anatominiais - fiziologiniais pokyčiais senatveje) ir išoriniai (susiję su nesaugia aplinka). Kritimų pavojų didina pablogejjusi pagyvenusių žmonių eisena, laikysena, susilpnèję raumenys. Regos ir klausos problemos, kitos lètinès ligos taip pat gali būti kritimų rizikos veiksniais. Nesaugi aplinka namuose bei keliuose, pagalbinių įtaisų bei priemonių stoka yra išoriniai kritimų rizikos veiksniai.

3. Pagrindinès pagyvenusių žmonių sužalojimų prevencijos priemonès yra pusiausvyros lavinimas, fizinio aktyvumo skatinimas ir saugios aplinkos kūrimas. Švietimas, informavimas, regos ir klausos problemų sprendimas, tinkamas medikamentų vartojimas, pagalbinių ịtaisų ir priemonių naudojimas yra rekomenduotinos priemonés, padedančios stiprinti pagyvenusių žmonių saugą ir mažinti kritimų riziką.

\section{Literatūra}

1. Juozulynas A., Stukas R., Jurgelènas A., Venalis A., Tamulaitytè-Morozoviené I. Pagyvenusių žmonių sveikata ir griuvimai. Gerontologija, 2012; 13(2): 103-106.

2. Piščalkienė V., Kavaliauskienè A., Zachovajevienė B., Gintilienė M., Rutkauskienė L. Vyresnio amžiaus asmenų griuvimo riziką lemiantys veiksniai. Sveikatos mokslai, 2012; 22 (5): 34-39.

http://dx.doi.org/10.5200/sm-hs.2012.094

3. WHO gobal report on falls prevention in older age. Geneva: World Health Organization, 2007.

4. Higienos institutas. Mirties priežastys 2014. Vilnius, 2015.

5. Spirginiené L., Riklikienẻ O. Komforto kontrolè ir griuvimų prevencija geriatrineje slaugoje. Gerontologija, 2011; 12(4): 259-264.

6. Daugèlienė E., Tamošiūnas A. Pagyvenusio amžiaus žmonių skaičiaus augimas bei jų sveikatos ypatybès. Lietuvos bendrosios praktikos gydytojas, 2007;11(6):420-424.

7. National Ageing Research Institute. Falls prevention supported residential services in the Western Metropolitan Region of Melbourne: Final Report 2002.

8. Mackevičius T. Senyvo amžiaus žmonių gyvenimo kokybès vertinimas. Magistro baigiamasis darbas, LKKA, 2010.

9. Bagdonas G., Damulevičienė G., Lesauskaitė V., Macijauskienè J., Valius L., Venstukonis D., Visokinskas A. Pagyvenusių žmonių sveikatos priežiūra. Kaunas. Vitae Litera, 2009.

10. Katilienè V. Ilgalaikẻ pagyvenusių ligotų žmonių slauga. Šiauliai. Liucijus, 2004.

11. Adomavičiūte D., Bylaite M., Bytautienė R., Bračiulienė I., Bukauskaitė L., Goštautaitė - Midttun N., Grubliauskienė A., Jotautienė L., Jucaitienė R., Juodžbalienė E., Kaladytė Lokominienè R., Karosienẻ Ž., Kisieliūtė A. ir kt. Sveikatos enciklopedija. Vilnius, 2003.

12. Kèvelaitis E., Illert M., Hultborn H. Žmogaus fiziologija. Kaunas. KMU, 2002.

13. Du Pasquier RA, Blanc Y, Sinnreich M, Landis T, Burkhard P, Vingerhoets FJ. The effect of aging on postural stability: a cross sectional and longitudinal study. Clinical Neurophysiology 2003; 33 (5): 213-218. http://dx.doi.org/10.1016/j.neucli.2003.09.001

14. Gauchard G, Gangloff P, Jeandel C, Perrin P. Physical activity improves gaze and posture control in the elderly. Neuroscience Research 2003; 45: 409-417. http://dx.doi.org/10.1016/S0168-0102(03)00008-7

15. Orrell AJ, Eves FF, Masters RSW. Motor learning of a dynamic balancing task after stroke: Implicit implications for stroke rehabilitation. Physical Therapy 2006; 86: 369 - 380.

16. Fujita T, Nakamura S, Ohue M, Fuji Y, Miyauchi A, Takagi Y, Tsugeno $\mathrm{H}$. Effect of age on body sway assessed by computerized posturography. Journal of Bone and Mineral Metabolism 2005; 23 (2): 152-156.

http://dx.doi.org/10.1007/s00774-004-0554-7

17. Onambele GL, Narici MV, Maganaris CN. Calf muscle tendon properties and postural balance in old age. Journal of Applied Physiology 2006; 100: 2048 - 2056.

http://dx.doi.org/10.1152/japplphysiol.01442.2005

18. TEACH-VIP 2. Geneva: World Health Organization 2012.

19. Sterling DA, O'Connor JA, Bonadies J. Geriatric falls: injury severity is high and disproportionate to mechanism. Journal of Trauma 2001; 50: 116-119. http://dx.doi.org/10.1097/00005373-200101000-00021

20. Stevens JA, Ballesteros MF, Mack KA, Rudd RA, De Caro E, Adler G. Gender differences in seeking care for falls in the aged medicare population. American Journal of Preventive Medicine 2012; 43: 59-62.

http://dx.doi.org/10.1016/j.amepre.2012.03.008

21. Center for Disease Control and Prevention (CDC). Web-based Injury Statistics Query and Reporting System (WISQARS). Atlanta: National Center for Injury Prevention and Control 2013. 
22. Gillespie LD, Gillespie WJ, Robertson MC, Lamb S. E. Cumming RG. Rowe BH. Interventions for preventing falls in elderly people. Cochrane Database System Review 2003; 4: CD000340.

http://dx.doi.org/10.1016/s0031-9406(05)60487-7

23. Alekna V., Šliažaitė R., Tamulaitienė M., Kalibatienė D. Pagyvenusių žmonių griuvimų dažnis ir aplinkybės. Sveikatos mokslai, 2002; 12(7): 73-77.

24. Tamulaitienė M., Alekna V., Tamulaitytė I., Juozulynas A. Senyvo amžiaus moterų griuvimai ir jų aplinkybès. Gerontologija, 2009; 10(3): 143-51.

25. Canadian Institute for Health Information. National Trauma Registry 2011 Report: Hospitalizations for major injury in Canada, 2008-2009 Data. Ottawa: 2011. Prieiga per internetą: https:// secure.cihi.ca/free_products/NTR_CDS_2008_2009_Annual_Report.pdf

26. Griškonis S., Strukčinskienė B., Raistenskis J., Strukčinskaitė V., Griškonytė I. Traumų dẻl nukritimų ypatumai pagyvenusių žmonių grupejje Lietuvoje. Sveikatos mokslai, 2013; 23(3): 12-15.

http://dx.doi.org/10.5200/sm-hs.2013.066

27. Marshall SW, Runyan CW, Yang J, Coyne-Beasley T, Waller AE, Johnson RM, Perkis D. Prevalence of selected risk and protective factors for falls in the home. American Journal of Preventive Medicine 2005; 28:95-101.

http://dx.doi.org/10.1016/j.amepre.2004.09.015

28. Maki BE, McIlroy WE, Fernie GR. Change-in-support reactions for balance recovery. IEEE. Engineering in Medicine and Biology Magazine 2003; 22(2): 20-6. http://dx.doi.org/10.1109/MEMB.2003.1195691

29. Rubenstein LZ. Falls in older people: epidemiology, risk factors and strategies for prevention. Age and Ageing, 2006; 35 (2): ii37-ii41.

http://dx.doi.org/10.1093/ageing/af1084

30. Goulburn Valley Health Service. Falls and elder people stepping into falls management. National Ageing Institute, 2009. Prieiga per internetą: http://health.vic.gov.au/agedcare/ maintaining/falls_dev/downloads/B1E2(2)\%20Falls\%20 and $\% 20$ older $\% 20$ people_Stepping $\% 20$ into $\% 20$ falls $\% 20$ management $\% 20$ ppt.pdf

31. Lin MR, Hwang HF, Wang YW, Chang SH, Wolf SL. Community-basedai Chi and its effect on injurious falls, balance, gait, and fear of falling in older people. Physical Therapy 2006; 86 (9): 1189-201. http://dx.doi.org/10.2522/ptj.20040408

32. Choi JH, Moon JS, Song R. Effects of Sun-style Tai Chi exercise on physical fitness and fall prevention in fall-prone older adults. Journal of Advanced Nursing 2005; 51 (2): 150-157. http://dx.doi.org/10.1111/j.1365-2648.2005.03480.x

33. Silsupadol P, Siu KC, Shumway-Cook A, Woollacott MH. Training of balance under single and dual task conditions in older adults with balance impairment. Physical Therapy 2006;
86: 269-281.

34. Ribeiro AS, Pereira JS. Balance improvement and reduction of likelihood of falls in older women after Cawthorne and Cooksey exercises. Brazilian Journal of Otorhinolaryngology 2005; 71(1): 38-6.

http://dx.doi.org/10.1016/S1808-8694(15)31283-0

35. Javtokas Z., Mačiūnas E. Pagyvenusių žmonių sveikatos stiprinimas. Vilnius: Valstybinis aplinkos sveikatos centras, 2008.

36. Gillespie LD, Handoll HHG. Prevention of falls and fall-related injuries in older people. Injury Prevention 2009; 15 (5): 354355 .

http://dx.doi.org/10.1136/ip.2009.023101

37. Forkan R, Pumper B, Smyth N, Wirkkala H, Ciol MA, Shumway-Cook A. Exercise adherence following physical therapy intervention in older adults with impaired balance. Physical Therapy 2006; 86(3): 401-410.

38. Česnaitienė V. J., Sipavičienè S., Juodžbalienė V. ir kt. Amžiaus ir fizinio aktyvumo poveikis kojų raumenų funkcinei būklei ir pusiausvyrai. Ugdymas. Kūno kultūra. Sportas, 2008; 2 (69): 11- 17.

39. Grivna M, Eid HO, Abu-Zidan FM. 2014. Epidemiology, morbidity and mortality from fall-related injuries in the United Arab Emirates. Journal of Trauma, Resuscitation and Emergency Medicine 22:51.

http://dx.doi.org/10.1186/s13049-014-0051-5

\section{FALLS IN ELDERLY: RISK FACTORS AND PREVENTION POSSIBILITIES}

\section{Strukčinskaitė, S. Norkienė, B. Strukčinskienė}

Key words: elderly, falls, risk factors, prevention.

Summary

Population aging is one of the twenty-first-century problems. Injuries are especially dangerous for elderly people since they contribute to the elderly mortality, disability and worsen the quality of life in older age.

The aim of the study was to analyze the risk factors of falls, and prevention possibilities in elderly. The literature overview and the document analysis were performed.

The study showed that falls are a main cause of death for the elderly. Fall risk factors are internal (related to the physiological changes in order age) and external (related to the unsafe environment).

Vision and hearing problems and other chronic diseases may also be risk factors for falls. Unsafe environment at home and on the road, the lack of assistive devices and tools are external risk factors for falls.

The main measures for the elderly injury prevention are balance training, physical activity promotion and safe environment creation. In addition, education, awareness enhancement, vision and hearing problems solution, appropriate use of medication, and assistive devices and tools are recommended measures for safety promotion and risk of falls reduction in elderly

Correspondence to: vaiva.struk@gmail.com

Gauta 2016-09-18 